\title{
Synthesis of esters of diaminotruxillic bis-amino acids by Pd-mediated photocycloaddition of analogs of the Kaede protein chromophore
}

\author{
Esteban P. Urriolabeitia ${ }^{* 1}$, Pablo Sánchez ${ }^{1}$, Alexandra Pop ${ }^{2}$, Cristian Silvestru ${ }^{2}$, \\ Eduardo Laga ${ }^{1}$, Ana I. Jiménez ${ }^{1}$ and Carlos Cativiela ${ }^{1}$
}

\author{
Full Research Paper \\ Address: \\ ${ }^{1}$ Instituto de Síntesis Química y Catálisis Homogénea, ISQCH (CSIC - \\ Universidad de Zaragoza), Pedro Cerbuna 12, E-50009 Zaragoza, \\ Spain and ${ }^{2}$ Supramolecular Organic and Organometallic Chemistry \\ Centre, Departament of Chemistry, Faculty of Chemistry and \\ Chemical Engineering, Babeş-Bolyai University, Str. Arany Janos 11, \\ RO-400028 Cluj-Napoca, Romania \\ Email: \\ Esteban P. Urriolabeitia* - esteban@unizar.es \\ * Corresponding author

\section{Keywords:} \\ amino acids; $\mathrm{C}-\mathrm{H}$ activation; Kaede protein; oxazolones; \\ photocycloaddition \\ Beilstein J. Org. Chem. 2020, 16, 1111-1123. \\ doi:10.3762/bjoc. 16.98 \\ Received: 15 April 2020 \\ Accepted: 08 May 2020 \\ Published: 25 May 2020 \\ Associate Editor: L. Ackermann \\ (c) 2020 Urriolabeitia et al.; licensee Beilstein-Institut. \\ License and terms: see end of document.
}

\begin{abstract}
The stereoselective synthesis of truxillic bis-amino esters from polyfunctional oxazolones is reported. The reaction of 4-((Z)-arylidene)-2-(E)-styryl-5(4H)-oxazolones 2 with $\operatorname{Pd}(\mathrm{OAc})_{2}$ resulted in ortho-palladation and the formation of a dinuclear open-book complexes $\mathbf{3}$ with carboxylate bridges, where the $\mathrm{Pd}$ atom is $\mathrm{C}^{\wedge} \mathrm{N}$ bonded to the oxazolone. In $\mathbf{3}$ the two exocyclic $\mathrm{C}=\mathrm{C}$ bonds of the oxazolone are in a face-to-face arrangement, which is optimal for their [2+2] photocycloaddition. Irradiation of dimers $\mathbf{3}$ in $\mathrm{CH}_{2} \mathrm{Cl}_{2}$ solution with blue light $(465 \mathrm{~nm})$ promoted the chemo- and stereoselective [2+2] photocycloaddition of the exocyclic $\mathrm{C}=\mathrm{C}$ bonds and the formation of cyclobutane-containing ortho-palladated complexes 4 . Treatment of $\mathbf{4}$ with $\mathrm{CO}$ in a $\mathrm{MeOH} / \mathrm{NCMe}$ mixture promoted the methoxycarbonylation of the palladated carbon and the release of the corresponding ortho-functionalized 1,3diaminotruxillic bis-amino esters $\mathbf{5}$ as single isomers.
\end{abstract}

\section{Introduction}

Truxillic acid derivatives (Figure 1a) are a special family of cyclobutanes that have been known since 1888 and show properties of high interest [1]. In this respect, their pharmacological activity has prompted extensive research that has focused on both their synthesis and the different pharmacological targets.
Among them, probably the most important is their remarkable intrinsic anti-inflammatory and antinociceptive action, for which some mechanisms have been postulated to explain this activity [2-6]. The interest in this type of compound has gained even more relevance in the last few years due to the discovery 
that truxillic acid derivatives are inhibitors of FABP (fatty acid binding proteins), which are responsible for the cellular reuptake of anandamide, an endocannabinoid neurotransmitter, and that they can be involved in a very efficient treatment for chronic pain [7-10]. Moreover, alternative mechanisms to explain the antinociception of truxillic compounds have also been reported [11,12] and have generated intense debate. In addition, truxillic derivatives have shown remarkable activity as hepato-protective agents [13] and they also have applications as internal donors in Ziegler-Natta catalysts for polymerization [14] or as building blocks in polymer chemistry [15].

A very closely related group of cyclobutanes are the 1,3diaminotruxillic ester derivatives (Figure 1b). This type of bisamino esters also shows remarkable pharmacological activity, not only as antinociceptive drugs but also in the treatment of type 2 diabetes mellitus. In fact, recent results have shown that these compounds are the only non-peptidic agonists of the GLP-1R (glucagon-like peptide 1 receptor) and they have a higher stability than any other agonist prepared to date [16-18]. The properties outlined above highlight the importance of the wide scope of applications of this set of cyclobutanes.

Despite their importance, access to most of these compounds mainly relies in the well-known [2+2] photocycloaddition of olefins [19]. Unfortunately, the synthesis of truxillic or diaminotruxillic derivatives is far from being a highly efficient, selective and general process. Two different cases are usually found in the literature: (a) the direct [2+2] photocycloaddition of the corresponding olefins takes place, but shows poor efficiency (long reaction times, harsh irradiation conditions and low yields) $[16,20]$, or $(b)$ the direct $[2+2]$ cycloaddition does not take place and it is necessary to synthesize a cyclobutane precursor and then functionalize it, thus increasing the number of reaction steps, the waste material, and decreasing the global yield $[16,21]$. Another drawback of these reactions is the selectivity, because good selectivity is achieved in photocycloadditions in solid state provided that the topochemical Schmidt's conditions are met [22-24], but the selectivity in solution is usually not as high $[25,26]$.

Our group is interested in the synthesis of 1,3-diaminotruxillic derivatives and we have made some contributions to this area of research [27-30]. Firstly, we demonstrated that ( $Z$ )-4-arylidene2-aryl-5(4H)-oxazolones (Figure 2a) are excellent precursors for the synthesis of this type of derivative, both by irradiation of the free species [27] and on using Pd complexes as templates [28-30]. The latter approach has shown good potential as a synthetic tool because it allows 1,3-diaminotruxillic derivatives to be obtained in a fully regio- and stereoselective way (only the $\varepsilon$-isomer is obtained). The process requires very mild reaction conditions in only three steps, with moderate to high yields in short reaction times under flow conditions [29], and it is compatible with substituents with different electronic properties (electron-releasing or electron-withdrawing) in the 4-arylidene

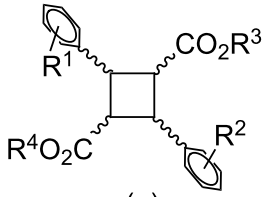

(a)

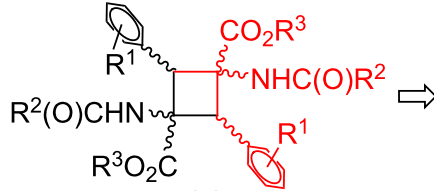

(b)<smiles>[R]C1=N/C(=C\c2cccc([R])c2)C(=O)O1</smiles>

(c)

Figure 1: (a) General scheme for truxillic acid derivatives; (b) general scheme for symmetric 1,3-diaminotruxillic ester derivatives; (c) retrosynthesis: 4-arylidene-5(4H)-oxazolones are optimal precursors.

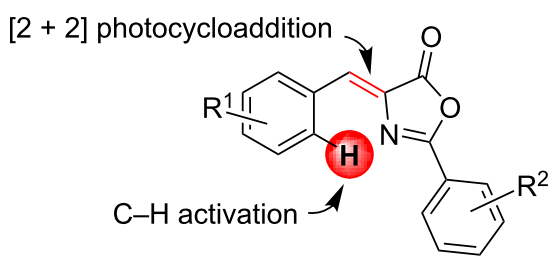

(a)

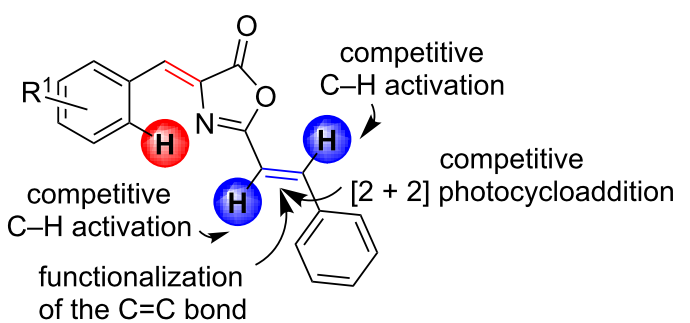

(b) $\mathrm{R}^{1}=\mathrm{F}, \mathrm{Cl}, \mathrm{CF}_{3}, \mathrm{NO}_{2}$

Figure 2: (a) (Z)-4-Arylidene-2-aryl-5(4H)-oxazolones used for the synthesis of 1,3-diaminotruxillic derivatives by direct [2 +2 ] photocycloaddition of the exocyclic $\mathrm{C}=\mathrm{C}$ bond or by incoporation of $\mathrm{Pd}$ to the oxazolone skeleton through $\mathrm{C}-\mathrm{H}$ activation followed by [2 +2 ] photocycloaddition; (b) $(Z)-4-$ arylidene-2((E)-styryl)-5(4H)-oxazolones studied in this work with all synthetic possibilities shown. 
ring. In addition, the ortho-position of the 2,4-aryl rings in the resulting bis-amino acids can be functionalized [30].

Substrates of the (Z)-4-arylidene-2((E)-styryl)-5(4H)-oxazolone type, shown in Figure 2b, are interesting starting materials for the synthesis of new 1,3-diaminotruxillic derivatives. These azlactones are precursors of the photoconvertible chromophore of the Kaede protein, an imidazolone with outstanding photophysical properties [31-38]. It is clear from Figure 2b that the molecular skeleton contains different reactive functional groups, which offer a variety of structural possibilities: two different competitive $\mathrm{C}=\mathrm{C}$ bonds amenable to undergo photocycloaddition and at least three different $\mathrm{C}-\mathrm{H}$ bonds that can be activated by a transition metal provide the potential for a rich organic and organometallic chemistry. Moreover, both the arylidene and the styryl groups can be tuned with different substituents to control the electronic and steric requirements of the ligand. We focused on precursors that have functional groups of interest $\left(\mathrm{F}, \mathrm{Cl}, \mathrm{CF}_{3}, \mathrm{NO}_{2}\right)$ as substituents in the 4-arylidene ring. In this way the final products will contain either a func- tional group that can be reacted further (for instance $\mathrm{C}-\mathrm{Cl}$, $\mathrm{C}-\mathrm{NO}_{2}$ ) or a functional group of interest from the medicinal or agrochemical point of view (for instance $\mathrm{C}-\mathrm{CF}_{3}, \mathrm{C}-\mathrm{F}$ ) [39-41]. However, their reactivity is still totally unexplored in terms of both $[2+2]$ photocycloaddition and metallations through $\mathrm{C}-\mathrm{H}$ bond activations. In the present contribution we report the results obtained for these two different processes.

\section{Results and Discussion Synthesis and characterization of the (Z)-4- arylidene-2((E)-styryl)-5(4H)-oxazolones 2}

The synthesis of the oxazolones $\mathbf{2}$ was carried out following the well-known Erlenmeyer-Plöchl method (Figure 3), by reaction of $N$-cinnamoylglycine (1) with the corresponding benzaldehyde $\mathrm{ArCHO}$ in acetic anhydride as solvent and in the presence of sodium acetate [42-48]. In turn, $N$-cinnamoylglycine (1) was prepared following the Schotten-Baumann method from glycine and cinnamoyl chloride [49]. All of the oxazolones used in this work are shown in Figure 3. The synthesis is quite

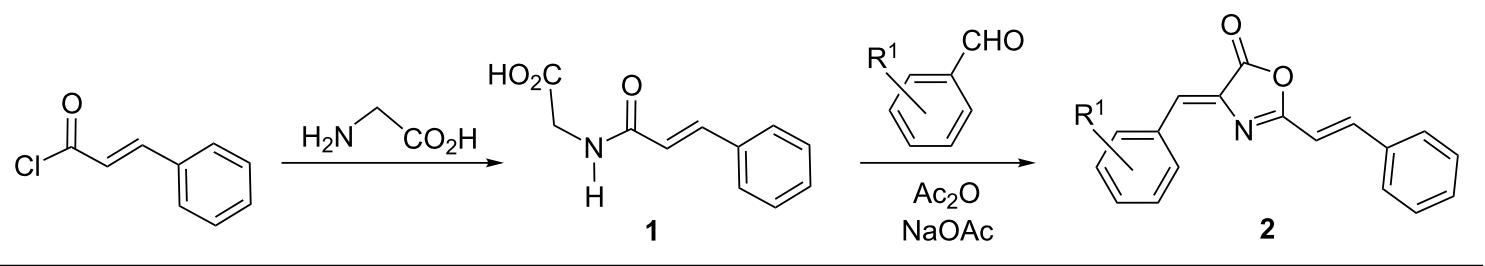<smiles>O=C1OC(/C=C/c2ccccc2)=N/C1=C\c1ccccc1F</smiles><smiles>O=C1OC(/C=C/c2ccccc2)=N/C1=C\c1ccc(F)cc1</smiles><smiles>O=C1OC(/C=C/c2ccccc2)=N/C1=C\c1ccccc1Cl</smiles><smiles>O=C1OC(/C=C/c2ccccc2)=N/C1=C\c1ccc(Cl)cc1</smiles><smiles>CC1=N/C(=C\c2ccccc2C(F)(F)F)C(=O)C1</smiles><smiles>C/C=C\C=C/C1=N/C(=C\c2ccc(C(F)(F)F)cc2)C(=O)O1</smiles><smiles>O=C1OC(/C=C/c2ccccc2)=N/C1=C\c1ccc(F)c(F)c1</smiles><smiles>C/C=C\C=C/C1=N/C(=C\c2ccc(Cl)c(Cl)c2)C(=O)O1</smiles>

$2 \mathrm{e}(22 \%)$<smiles></smiles>

$2 f(31 \%)$<smiles>O=C1OC(/C=C/c2ccccc2)=N/C1=C\c1ccccc1[N+](=O)[O-]</smiles><smiles>O=C1OC(/C=C/c2ccccc2)=N/C1=C\c1ccc([N+](=O)[O-])cc1</smiles>

Figure 3: (Z)-4-Arylidene-2((E)-styryl)-5(4H)-oxazolones 2a-j used in this work and overall reaction scheme. 
general and tolerates substituents at different positions of the 4-arylidene ring, although the yields are only moderate to low. The lowest yields correspond to ortho-substituted substrates, which suggests that steric hindrance plays a role during the reaction. Oxazolones $\mathbf{2} \mathbf{a}-\mathbf{j}$ contain two exocyclic $\mathrm{C}=\mathrm{C}$ bonds in their skeleton and these can, in principle, have different conformations. The NMR characterization of $\mathbf{2} \mathbf{a}-\mathbf{j}$ showed that they are obtained as single isomers. The oxazolone exocyclic $\mathrm{C}=\mathrm{C}$ bond has the $(Z)$-configuration, because the signal assigned to the $C=\mathrm{O}$ group appears as a doublet in the proton-coupled ${ }^{13} \mathrm{C}$ NMR spectrum, with a ${ }^{3} J_{\mathrm{CH}}$ coupling constant of $5.6 \mathrm{~Hz}$ [50]. In contrast, the $\mathrm{C}=\mathrm{C}$ bond of the styryl group has an $(E)$ configuration, as inferred from the observation of a ${ }^{3} J_{\mathrm{HH}}$ coupling constant of $16 \mathrm{~Hz}$ between the two olefinic protons of the styryl fragment.

Further characterization of the new oxazolones was provided by the determination of the crystal structure of oxazolone 2c. A molecular drawing of $\mathbf{2 c}$ is shown in Figure 4, where the $(Z)$ configuration of the exocyclic $\mathrm{C}=\mathrm{C}$ bond $(\mathrm{C} 7-\mathrm{C} 8)$ and the $(E)$ configuration of the styryl moiety $(\mathrm{C} 11-\mathrm{C} 12)$ are clearly seen, thus confirming the results obtained in solution. It is worth noting the orientation of the chlorine atom $\mathrm{Cl1}$, which is syn with respect to the benzylidene proton. This orientation minimizes steric repulsions in the molecule and allows the establishment of an intramolecular contact between $\mathrm{Cl} 1$ and H7A. The non-bonding distance $\mathrm{Cl1}-\mathrm{H} 7 \mathrm{~A}$ is $2.565(3) \AA$, which is much shorter than the sum of the van der Waals radii (2.95 $\AA$ ) [51] The same syn arrangement between the ortho-substituent and the benzylidene proton has also been observed in related orthosubstituted unsaturated 4-arylidene-oxazolones [52-59]. The internal bond distances and angles for the 4-arylidene fragment and the oxazolone ring are similar or identical, within experimental error, to those found in related oxazolones reported in the literature [52-59]. The styryl fragment bonded to an oxazolone ring has not been characterized previously by X-ray methods, but it shows internal bond distances and angles similar to those found in related 2-styrylimidazolone species [60].

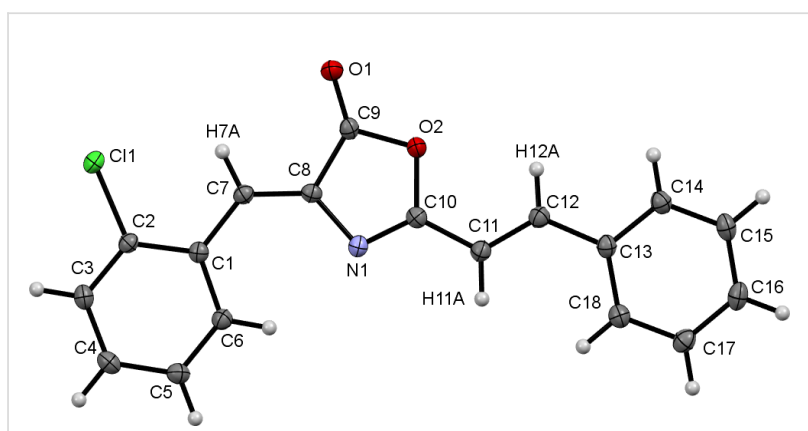

Figure 4: Molecular drawing of the oxazolone 2c.

\section{$\mathrm{C}-\mathrm{H}$ Bond activation processes on (Z)-4- arylidene-2((E)-styryl)-5(4H)-oxazolones 2}

Once the starting oxazolones 2 had been prepared, their direct $[2+2]$ photocycloaddition was attempted. However, irradiation of solutions of 2 in $\mathrm{CD}_{2} \mathrm{Cl}_{2}$ with blue LED light (465 nm), under the same conditions as reported previously by us for similar oxazolones [27], did not produce the expected cyclobutanes or gave only very low conversions $(<5 \%)$ after long reaction times $(96 \mathrm{~h})$. As this reactivity was poor, it was decided to attempt the reaction using Pd complexes as templates [28-30]. The first step in this process was to study the $\mathrm{C}-\mathrm{H}$ bond activation in oxazolones 2 promoted by $\mathrm{Pd}(\mathrm{OAc})_{2}$, which shows multiple possibilities (Figure 2b).

Treatment of the oxazolones $\mathbf{2 a}-\mathbf{j}$ with $\mathrm{Pd}(\mathrm{OAc})_{2}(1: 1$ molar ratio) in $\mathrm{CF}_{3} \mathrm{CO}_{2} \mathrm{H}$ as solvent under reflux for $2 \mathrm{~h}$ resulted in the formation of the dinuclear complexes $\mathbf{3 a}-\mathbf{f}$ and $\mathbf{3 h}-\mathbf{j}$, as shown in Scheme 1. In the case of oxazolone $2 \mathrm{~g}$ a very complex mixture was obtained and a pure compound could not be isolated.<smiles></smiles>

$2 a-j$

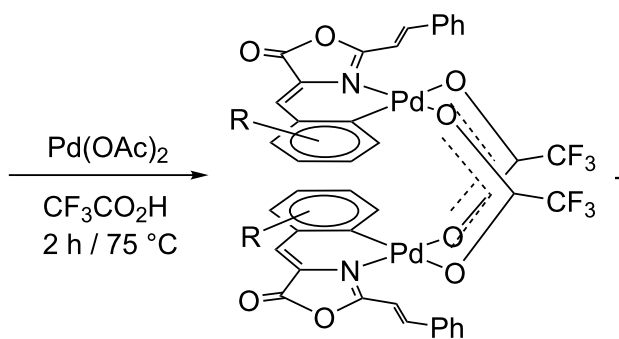

$3 a-f, 3 h-j$

transoid (major isomer)

3f $(85 \%)$, 3h (94\%), 3i (66\%), 3j (85\%) 
Complexes 3 were obtained as air- and moisture-stable solids in good yields (see Experimental and Supporting Information File 1). In general, the yields were higher than $85 \%$, which shows that the $\mathrm{C}-\mathrm{H}$ activation is a general process and that the presence of strong electron-withdrawing groups is not an obstacle for the synthesis of the ortho-palladated derivatives. Only in the case of complexes $\mathbf{3 e}$ and $\mathbf{3 i}$ were the yields slightly lower than in the other cases ( $70 \%$ and $66 \%$, respectively), probably due to two simultaneous factors, namely the presence of bulky $\mathrm{CF}_{3}$ and $\mathrm{NO}_{2}$ groups in ortho positions of the starting oxazolones $2 \mathbf{e}$ and $\mathbf{2 i}$, and the strongly deactivating effect of the two groups on the $\mathrm{C}-\mathrm{H}$ bond activation process. The reactions were usually carried out using $0.6 \mathrm{mmol}$ of the starting material 2. In this respect, it is remarkable that the $\mathrm{C}-\mathrm{H}$ activation allows in this case scale-up of the reaction without a loss of yield. For oxazolone $\mathbf{2 h}$ the reaction was carried out using $4.3 \mathrm{mmol}$ of starting material and the final yield of analytically pure $\mathbf{3 h}$ was 94\% (see Experimental).

The characterization of complexes $\mathbf{3}$ shows that they are obtained as dinuclear derivatives, as inferred from the HRMS spectra. The oxazolone is bonded to the $\mathrm{Pd}(\mathrm{II})$ center as a $\mathrm{C}, \mathrm{N}$ chelate, as inferred by analysis of the ${ }^{1} \mathrm{H}$ NMR spectra. The spectra show that the spin system of the styryl fragment $-\mathrm{C}(\mathrm{H})=\mathrm{C}(\mathrm{H}) \mathrm{Ph}$ remains unaltered after the reaction, while the spin system of the 4-arylidene fragment $\left(\mathrm{R}-\mathrm{C}_{6} \mathrm{H}_{4}-\mathrm{C}(\mathrm{H})=\right)$ changed to $\mathrm{R}-\mathrm{C}_{6} \mathrm{H}_{3}-\mathrm{C}(\mathrm{H})=$, thus showing the loss of one ortho$\mathrm{H}$. This strongly suggests that the $\mathrm{C}-\mathrm{H}$ bond activation and incorporation of the Pd atom had occurred chemo- and regioselectively at the 4 -arylidene ring. The same conclusions can be drawn from the analysis of the ${ }^{13} \mathrm{C}$ NMR spectra, where the presence of the $\mathrm{PdC}_{6} \mathrm{H}_{3} \mathrm{R}-\mathrm{C}(\mathrm{H})=$ group is clear. Therefore, the orientation of the $\mathrm{C}-\mathrm{H}$ activation in these 4-aryliden-2-styryloxazolones is exactly the same as that observed for the 4-aryliden-2-aryloxazolones [28-30,56]. Signals corresponding to the activation of other $\mathrm{C}-\mathrm{H}$ bonds present in oxazolones 2 (styryl, aryl) were not observed, so the reaction shows full selectivity towards the ortho-arylidene positions despite the presence of different $\mathrm{C}-\mathrm{H}$ bonds that could be activated. Considering the dinuclear nature of compounds 3 , the C,Nchelate bonding mode of the ortho-palladated oxazolone and the ability of the carboxylate group to act as a bridging ligand in related complexes, we propose for complexes $\mathbf{3 a}-\mathbf{f}$ and $\mathbf{3 h}-\mathbf{j}$ the 'open-book' structure shown in Scheme 1.

The dimeric open-book structures of $\mathbf{3}$ can result in the formation of two isomers, the transoid (in which the two cyclopalladated oxazolones are in an anti arrangement) and the cisoid (syn arrangement). The presence of the two isomers in $\mathbf{3}$ is clear from the observation of two sets of signals due to the $\mathrm{CF}_{3} \mathrm{CO}_{2}{ }^{-}$ ligand in the ${ }^{19} \mathrm{~F}$ NMR spectra. The major isomer shows one singlet and this is assigned by symmetry to the transoid isomer, while the minor isomer shows two singlets and is assigned to the cisoid isomer. The transoid isomer is always the most abundant one, with transoid/cisoid ratios in the range from 70:30 (3i) to $96: 4$ (3h). Only the major transoid isomer in the mixture was fully characterized (see Experimental).

\section{Reactivity of ortho-palladated complexes 3 with light: intramolecular [2 + 2] photocycloaddition}

Despite the lack of reactivity of free oxazolones 2 with blue light $(465 \mathrm{~nm})$, irradiation of the ortho-palladated complexes 3 with light of the same wavelength afforded better results. The irradiation of dinuclear derivatives $\mathbf{3 a}-\mathbf{f}$ and $\mathbf{3 h}-\mathbf{j}$ in $\mathrm{CH}_{2} \mathrm{Cl}_{2}$ solution with blue light $(465 \mathrm{~nm})$, provided by low-power LED lamps, took place with chemoselective $[2+2]$ photocycloaddition of the oxazolone exocyclic $\mathrm{C}=\mathrm{C}$ bonds and formation of the corresponding ortho-palladated cyclobutane derivatives $4 \mathbf{a}-\mathbf{f}$ and $\mathbf{4 h}-\mathbf{j}$, as shown in Scheme 2.

Complexes $\mathbf{4 a - f}$ and $\mathbf{4 h}-\mathbf{j}$ were obtained as air- and moisturestable solids in good to very good yields. This also applied to the synthesis of $\mathbf{4 h}$, which was performed at scale of $2 \mathrm{mmol}$

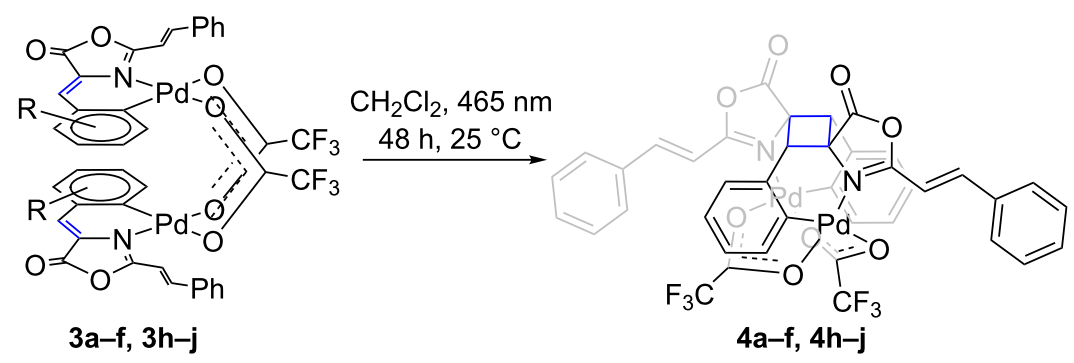

4a (90\%), 4b (91\%), 4c (80\%), 4d (68\%), 4e (60\%)

$4 f(71 \%), 4 h(96 \%), 4 i(69 \%), 4 j(81 \%)$ 
(instead of $0.2 \mathrm{mmol}$ in most of the other cases) and was obtained with $96 \%$ isolated yield. In order to understand the different reactivities of oxazolones $\mathbf{2}$ and complexes $\mathbf{3}$ towards light, the absorption UV-vis spectra of the oxazolones $\mathbf{2}$ and ortho-palladated complexes $3\left(\mathrm{CH}_{2} \mathrm{Cl}_{2}, 5 \times 10^{-4} \mathrm{M}\right)$ were measured and this provided some clues. The positions of the absorption maxima $\left(\lambda_{\max }, \mathrm{nm}\right)$ for both species are collected in Table 1.

Table 1: UV-vis spectra of 2 and 3: absorption maxima $\left(\lambda_{\max }, \mathrm{nm}\right)$

oxazolones 2 complexes 3

\begin{tabular}{lll}
\hline a & 379 & 457 \\
b & 376 & 454 \\
c & 377 & 459 \\
d & 381 & 459 \\
e & 375 & 467 \\
f & 380 & 461 \\
h & 381 & 466 \\
i & 383 & 464 \\
j & 385 & 457 \\
\hline
\end{tabular}

According to the data in Table 1, the maximum absorption for oxazolones $\mathbf{2}$ is located in the near UV region, in the range of $375-385 \mathrm{~nm}$, and this is quite far from the irradiation wavelength $(465 \mathrm{~nm})$. In fact, at $465 \mathrm{~nm}$ the UV-vis spectra of oxazolones 2 show that the absorption is zero or close to zero. Therefore, the lack of reactivity of species $\mathbf{2}$ can be related with the absence of the absorption of light. However, the ortho-palladation causes a clear bathochromic shift from compounds $\mathbf{2}$ to $\mathbf{3}$ and this results in absorption maxima for complexes $\mathbf{3}$ located in the range of 454-467 $\mathrm{nm}$. In this case the use of blue light $(465 \mathrm{~nm})$ is optimal for their irradiation, because the irradiation wavelength matches the maximum absorption.

NMR characterization of complexes 4 showed that all compounds were obtained as a single stereoisomer, despite the presence of two isomers in the starting materials 3. The ${ }^{1} \mathrm{H}$ NMR and ${ }^{13} \mathrm{C}$ NMR spectra clearly showed the chemical equivalence of the two ortho-palladated fragments, while ${ }^{19} \mathrm{~F}$ NMR spectra showed the equivalence of the bridging trifluoroacetate ligands. This means that only the transoid isomers of complexes $\mathbf{3}$ were transformed into cyclobutanes $\mathbf{4}$, as shown in Scheme 2. The small amount of cisoid isomer in $\mathbf{3}$ probably decomposed under the reaction conditons, because in some cases the presence of small amounts of black $\mathrm{Pd}^{0}$ was observed. The formation of the cyclobutane ring is inferred in the ${ }^{1} \mathrm{H}$ NMR spectra from the disappearance from the aromatic region of the signal due to the vinyl proton of the oxazolone exocyclic $\mathrm{C}=\mathrm{C}$ bond and the appearance of a new singlet in the 4.8-5.7 ppm region. Further evidence can be found in the ${ }^{13} \mathrm{C}$ NMR spectra, where the two peaks due to the exocyclic $\mathrm{C}(\mathrm{H})=\mathrm{C}$ bond disappeared and two new signals appeared at around 68-69 ppm (quaternary $\mathrm{C}$ ) and 51-60 ppm (CH). These facts are consistent with the expected hybridization change from $\mathrm{Csp}^{2}$ to $\mathrm{Csp}^{3}$ after formation of the cyclobutane ring.

Determination of the crystal structure of complex $\mathbf{4 a}$, which is shown in Figure 5, provides additional information. Complex 4a has a dinuclear structure in which each $\mathrm{Pd}$ atom is surrounded by one $\mathrm{C}, \mathrm{N}$-ortho-metallated oxazolone and two oxygen atoms of the trifluoroacetate ligands, which act as bridging ligands between the two $\operatorname{Pd}\left(\mathrm{C}^{\wedge} \mathrm{N}\right)$ fragments. In turn,

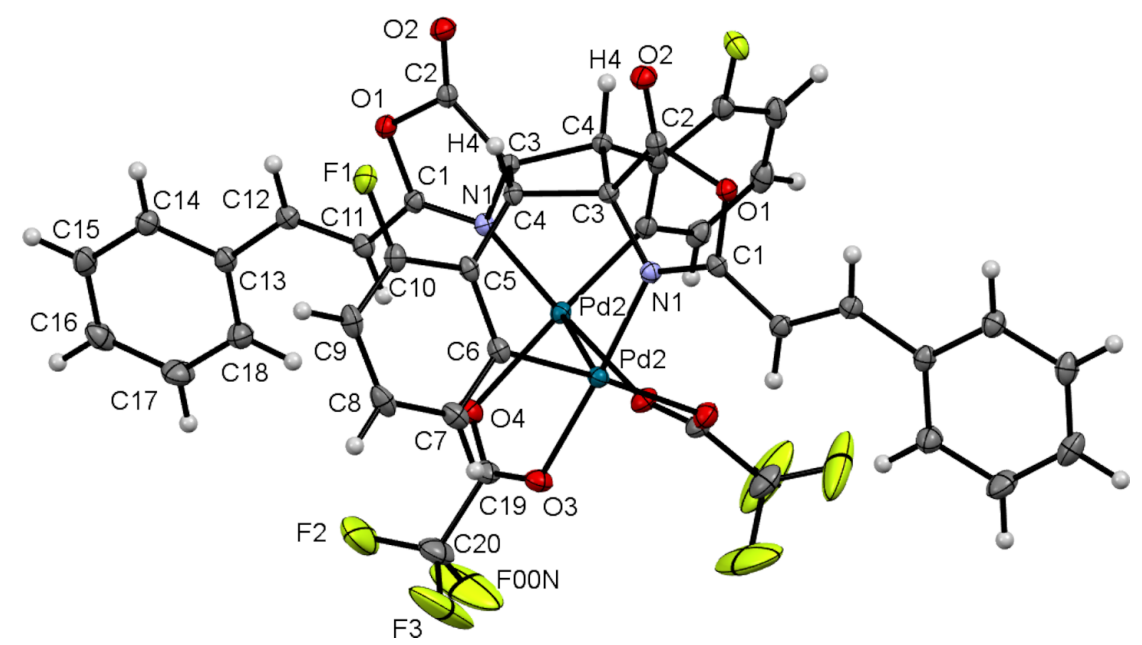

Figure 5: Molecular drawing of cyclobutane ortho-palladated 4a. Ellipsoids are shown at the 50\% probability level. 
the two $\operatorname{Pd}\left(\mathrm{C}^{\wedge} \mathrm{N}\right)$ fragments are linked by the cyclobutane ring formed by $[2+2]$ photocycloaddition of the oxazolone exocyclic $\mathrm{C}=\mathrm{C}$ bonds. The resulting configuration of the $\mathrm{C} 3-\mathrm{C} 4-\mathrm{C} 3$ '-C4' cyclobutane ring, in which the carbonyl groups are on one side of the plane containing the cyclobutane and the nitrogen and the ortho-palladated ring on the other side of the plane, shows that the compound obtained is the epsilon $(\varepsilon)$ isomer, according to the classification of Stoermer [61,62]. The non-bonding intramolecular distance between the ortho-fluorine $\mathrm{F} 1$ and the cyclobutane proton $\mathrm{H} 4$ is $\mathrm{d}(\mathrm{F} 1 \cdots \mathrm{H} 4)=$ 2.286(3) $\AA$, which is much shorter than the sum of the van der Waals radii $(2.67 \AA$ ) [51]. This suggest a close interaction between these two atoms, as observed in the crystal structure of $\mathbf{2 c}$ (see above). The analysis of other internal bond distances and angles in the coordination sphere of the Pd atom shows that they are similar to those found in related examples reported in the literature and do not show additional noteworthy features [28-30].

From the observation of the molecular structure of $\mathbf{4 a}$, it is clear how the geometrical constraints of the ligands in complexes 3 establish unequivocally the stereoselective formation of the $\varepsilon$-isomer in 4: (1) the initial ( $Z$ )-configuration of the oxazolones $\mathbf{2}$ is retained during the $\mathrm{C}-\mathrm{H}$ bond activation step to give $\mathbf{3}$ (2) the relative transoid arrangement in $\mathbf{3}$ establishes the 1,3head-to-tail coupling of the exocyclic $\mathrm{C}=\mathrm{C}$ bonds; (3) the template effect of the $\mathrm{Pd}_{2}\left(\mathrm{O}_{2} \mathrm{CCF}_{3}\right)_{2}$ moiety establishes the syn approach of the $\mathrm{C}=\mathrm{C}$ bonds. As a result, only the $\varepsilon$-isomer can be obtained and the stereoselectivity of the method is complete. As discussed previously, photocycloaddition products from the $[2+2]$ reaction of the cisoid isomers of $\mathbf{3}$ were not observed, and we are unaware of the reasons for this lack of reactivity.

\section{Release of the 1,3-truxillic derivative by methoxycarbonylation}

The last step to achieve the synthesis of the 1,3-diaminotruxillic targets was the release of the cyclobutane from the $\mathrm{Pd}_{2}\left(\mathrm{O}_{2} \mathrm{CCF}_{3}\right)_{2}$ template. We previously reported that hydrogenation and halogenation were adequate tools to liberate 1,3 diaminotruxillics from the organopalladium template $[29,30]$ We employed similar reactions in this case with complexes $\mathbf{4}$ but none of the attempts gave satisfactory results. Therefore, we discarded them and investigated other alternatives.

We found that the reaction of ortho-palladated complexes 4 with $\mathrm{CO}$ in methanol is a good option to promote the liberation of the organic cyclobutane, while retaining the functionalities already present $\left(\mathrm{C}-\mathrm{F}, \mathrm{C}-\mathrm{Cl}, \mathrm{C}-\mathrm{NO}_{2}, \mathrm{C}-\mathrm{CF}_{3}\right.$ and $-\mathrm{C}(\mathrm{H})=\mathrm{C}(\mathrm{H})-$ groups) and introducing a new functionality, i.e., the methoxycarbonyl group, selectively at the ortho-position of the aryl rings bonded to carbons $\mathrm{C} 2$ and $\mathrm{C} 4$ of the cyclobutane. Alkoxy- carbonylation is a well-known reaction in $\mathrm{Pd}(\mathrm{II})$ chemistry [6366]. Therefore, treatment of solutions of cyclobutanes 4 in a mixture of $\mathrm{MeOH} / \mathrm{NCMe}(1: 3)$ with $\mathrm{CO}$ (1 atm) at room temperature proceeded with decomposition of the organometallic core, precipitation of black $\mathrm{Pd}^{0}$ and concomitant formation of the cyclobutanes 5, as represented in Scheme 3.

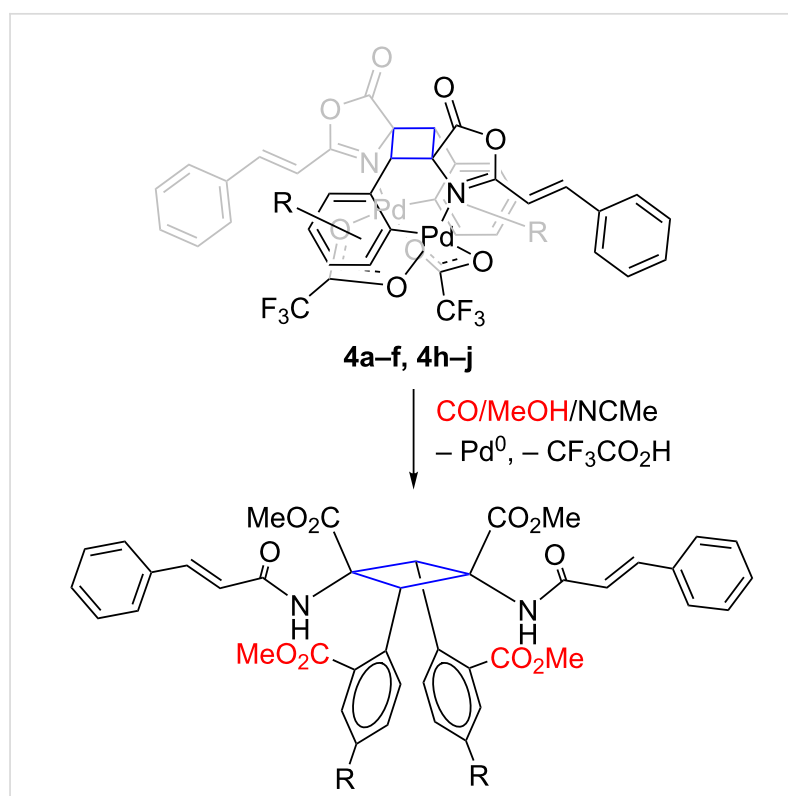

5b (84\%), 5d (83\%), 5f (67\%), 5h (91\%), 5j (53\%)

Scheme 3: Release of the 1,3-diaminotruxillic bis-amino ester derivatives 5 by methoxycarbonylation of the $\mathrm{Pd}-\mathrm{C}$ bond in cyclobutanes 4 and reductive elimination.

The methoxycarbonylation reaction to give $\mathbf{5}$ was not as general as the previous steps to give oxazolones $\mathbf{2}$ or cyclopalladated $\mathbf{3}$ and 4 . In the case of para- or meta-aryl-substituted derivatives 4 $(\mathbf{4 b}, \mathbf{4 d}, \mathbf{4 f}, \mathbf{4 h}$ and $\mathbf{4 j})$ the reaction gave the corresponding cyclobutanes $(\mathbf{5 b}, \mathbf{5 d}, \mathbf{5 f}, \mathbf{5 h}$ and $\mathbf{5 j})$ in moderate to good yields, but in the cases of the ortho-substituted compounds (4a, 4c, 4e, 4i) intractable mixtures were obtained. The presence of two ortho-substituents in both aryl rings of the cyclobutanes (at $\mathrm{C} 2$ and C4) probably resulted in a strong steric hindrance around the already crowded cyclobutane ring, which gave rise to instability and decomposition. However, it is remarkable that all functional groups present in the starting materials $4(\mathrm{C}-\mathrm{F}, \mathrm{C}-\mathrm{Cl}$, $\mathrm{C}-\mathrm{NO}_{2}, \mathrm{C}-\mathrm{CF}_{3}$ and $-\mathrm{C}(\mathrm{H})=\mathrm{C}(\mathrm{H})-$ ) remained intact after the reaction, even in the presence of stoichiometric amounts of $\mathrm{Pd}^{0}$.

The presence of NCMe in large amounts in the reaction medium is critical. The reaction in methanol takes place at a very low rate but this increases markedly when NCMe is present. After a short screening of $\mathrm{MeOH} / \mathrm{NCMe}$ ratios it was found that 1:3 was optimal. The ${ }^{1} \mathrm{H}$ NMR spectrum of complex $\mathbf{4 h}$ in $\mathrm{NCMe} / \mathrm{NCMe}-d_{3}$ shows the presence of Pd-coordinated $\mathrm{NCMe}$, 
which suggests that the role of the NCMe is the decoordination of the bridging carboxylate ligands by ligand exchange. The substitution of the bridging $\mathrm{CF}_{3} \mathrm{CO}_{2}$ by monodentate $\mathrm{NCMe}$ probably destabilizes the compact dinuclear scaffold, thus helping the coordination and further reactivity of $\mathrm{CO}$. Nevertheless, the reaction is slow because it took about $16 \mathrm{~h}$ to reach completion. The reaction temperature is also critical, since room temperature is necessary in order to obtain a clean release of the truxillic esters. In addition to the methoxycarbonylation of the $\mathrm{Pd}-\mathrm{C}$, the reaction also involves ring opening of the oxazolone moiety to afford the corresponding ester and amido groups. This ring opening was also observed in the case of the hydrogenation and probably minimizes the steric strain around the cyclobutane ring.

The characterization of cyclobutanes $\mathbf{5}$ was performed by the usual methods. The HRMS spectra confirmed the loss of the $\mathrm{Pd}_{2}\left(\mathrm{O}_{2} \mathrm{CCF}_{3}\right)_{2}$ unit and showed isotopic patterns in perfect agreement with the proposed stoichiometries. The ${ }^{1} \mathrm{H}$ NMR spectra show in all cases the presence of two different $\mathrm{CO}_{2} \mathrm{Me}$ units and one $\mathrm{N}(\mathrm{H}) \mathrm{C}(\mathrm{O}) \mathrm{C}(\mathrm{H})=\mathrm{C}(\mathrm{H}) \mathrm{Ph}$ moiety, thus demonstrating the incorporation of the methoxycarbonyl group and the ring opening of the oxazolone by methanol. The expected signals for the aryl and cyclobutane rings are also observed. These findings were also confirmed by analysis of the ${ }^{13} \mathrm{C}$ NMR spectra.

\section{Conclusion}

The synthesis of cyclobutane 1,3-diaminotruxillic bis-amino acids has been achieved with full stereoselectivity ( $\varepsilon$-isomer) starting from polyfunctional oxazolones 2 derived from the chromophore of the Kaede protein in three steps. The new $(Z)$ 4-arylidene-2-(E)-styryl-5(4H)-oxazolones 2 react with $\mathrm{Pd}(\mathrm{OAc})_{2}$ through a $\mathrm{C}-\mathrm{H}$ bond activation reaction to give the dinuclear 'open-book' ortho-palladated complexes $\left[\mathrm{Pd}_{2}(\mu\right.$ $\left.\mathrm{O}_{2} \mathrm{CCF}_{3}\right)_{2}\left(\mathrm{C}^{\wedge} \mathrm{N}\right.$-oxa $\left.\left.)\right)_{2}\right] 3$ with bridging carboxylate ligands. Despite the presence in $\mathbf{2}$ of different functional groups and different types of $\mathrm{C}-\mathrm{H}$ bonds that could be activated, the $\mathrm{C}-\mathrm{H}$ activation takes place regioselectively at the ortho-position of the 4-arylidene ring and leaves the remaining functional groups $\left(\mathrm{C}-\mathrm{F}, \mathrm{C}-\mathrm{Cl}, \mathrm{C}-\mathrm{NO}_{2}, \mathrm{C}-\mathrm{CF}_{3}, \mathrm{C}(\mathrm{H})=\mathrm{C}(\mathrm{H})\right)$ intact. The 'openbook' complexes 3 show a face-to-face arrangement of the exocyclic $\mathrm{C}=\mathrm{C}$ bonds of the oxazolone, which is optimal for their [2 + 2] photocycloaddition. Accordingly, irradiation of $\mathbf{3}$ with blue light $(465 \mathrm{~nm})$ results in the regioselective formation of the corresponding dinuclear ortho-metallated cyclobutane complexes 4, which contain the skeleton of the 1,3diaminotruxillic bis-amino acids. The reaction of the cyclobutanes 4 with $\mathrm{CO}(1 \mathrm{~atm})$ in $\mathrm{MeOH} / \mathrm{NCMe}$ results in the ring opening of the oxazolone group, methoxycarbonylation of the $\mathrm{Pd}-\mathrm{C}$ bonds, reductive elimination, and finally release of the 1,3-diaminotruxillic bis-amino esters 5 as single isomers ( $\varepsilon$-isomer).

The method shows great synthetic potential due to the selective formation of a single isomer, versatility and efficiency (high yields), general applicability and tolerance to the presence of different functional groups, although it is partially limited by steric hindrance in the final step. In addition, this approach allows the scale-up of the reaction without loss of yield of the final products.

\section{Experimental General methods}

Solvents were obtained from commercial sources and used without further purification. All reactions were performed without special precautions against water and moisture. Thin-layer chromatography (TLC) was performed on Macherey-Nagel Polygram ${ }^{\circledR}$ SIL G/UV254 silica gel on polyester sheets, with manganese-activated zinc silicate with green fluorescence for short-wave UV (254 nm) and special inorganic fluorescent pigment with blue fluorescence for long-wave UV (366 nm) as indicators. Fluka silica gel (pore size $60 \AA$, 70-230 mesh, 63-200 $\mu \mathrm{m}$ ) was used for gravity column chromatography. C, $\mathrm{H}, \mathrm{N}$ and $\mathrm{S}$ elemental microanalyses were carried out on a Perkin-Elmer 2400-B Series II Analyzer. High-resolution mass spectra-ESI (HRMS-ESI) were recorded using a Bruker MicroToF-Q ${ }^{\text {TM }}$ equipped with an API-ESI source and a Q-ToF mass analyzer. Acetonitrile and methanol were used as solvents. Samples were introduced at a continuous flow of $0.2 \mathrm{~mL} / \mathrm{min}$, and nitrogen served both as the nebulizer gas and the dry gas. Infrared spectra were recorded on a Spectrum 100 Perkin-Elmer FTIR spectrophotometer, with a universal attenuated total reflectance (UATR) accessory made of thallium bromide-iodide crystals (KRS-5). The ${ }^{1} \mathrm{H},{ }^{13} \mathrm{C}\left\{{ }^{1} \mathrm{H}\right\}$ and ${ }^{19} \mathrm{~F}$ NMR spectra were recorded on Bruker Avance-300 and -400 spectrometers ( $\delta$ in $\mathrm{ppm} ; J$ in $\mathrm{Hz}$ ). All spectra were recorded at room temperature in solution, using $\mathrm{CDCl}_{3}$ as deuterated solvent (different conditions will be indicated). The ${ }^{1} \mathrm{H}$ and ${ }^{13} \mathrm{C}\left\{{ }^{1} \mathrm{H}\right\}$ spectra are referenced using the residual solvent signal as internal standard, while ${ }^{19} \mathrm{~F}$ spectra are referenced to $\mathrm{CFCl}_{3}$. The ${ }^{1} \mathrm{H}$ NMR peaks were assigned through standard $2 \mathrm{D}{ }^{1} \mathrm{H}-\mathrm{COSY}\left(2 \mathrm{~K}\right.$ points in $t_{2}$ using a spectral width of $10 \mathrm{ppm} ; 128 t_{1}$ experiments were recorded and zero-filled to $1 \mathrm{~K}$; for each $t_{1}$ value four scans were signal-averaged using a recycle delay of $1 \mathrm{~s}$ ) and selective 1D ${ }^{1} \mathrm{H}$-NOESY experiments. Typical mixing times in the case of selective 1D-NOESY experiments were in the range 1.2-1.8 s as a function of the irradiated signal. These optimized mixing times were set to be equal to the longitudinal relaxation time $t_{1}$, determined using the inversion-recovery sequence. The ${ }^{13} \mathrm{C}$ NMR peaks were identified using standard ${ }^{1} \mathrm{H}-{ }^{13} \mathrm{C}$ editedHSQC and ${ }^{1} \mathrm{H}-{ }^{13} \mathrm{C}$ HMBC $2 \mathrm{D}$-experiments. In both cases $4 \mathrm{~K}$ 
points in $t_{2}$ using spectral widths of $10 \mathrm{ppm}\left({ }^{1} \mathrm{H}\right)$ and $200 \mathrm{ppm}$ $\left({ }^{13} \mathrm{C}\right)$ were used, with averaged values of the coupling constants ${ }^{1} J_{\mathrm{CH}}=145 \mathrm{~Hz}$ and long-range ${ }^{n} J_{\mathrm{CH}}=10 \mathrm{~Hz}$. Typically, $256 t_{1}$ experiments were recorded and zero-filled to $2 \mathrm{~K}$. For each $t_{1}$ value 8 (HSQC) or 32 (HMBC) scans were signal-averaged using a recycle delay of $1 \mathrm{~s}$. Absorption spectra were measured on a Thermo Scientific Evolution 600BB spectrophotometer. Cinnamoylglycine (1) was prepared by the Schotten-Baumann method [49].

\section{Irradiation setup for batch synthesis}

The irradiation setup consisted of a flask $(100 \mathrm{~mL})$ irradiated by a printed circuit board (PCB) formed by 24 LEDs of $10 \mathrm{~mm}$ diameter each LED. The LEDs were serially connected in blocks of 6 , with the minimum voltage possible $(3 \mathrm{~V})$ and a resistance of $60 \Omega$ (according to Ohm's law). The output power per LED unit (blue, $465 \mathrm{~nm}$ ) was $250 \mathrm{kmcd}$; the optical output power of the PCB of LEDs measured with a photometer (PM100D, Thorlabs) was $1 \mathrm{~W}$. The PCB (dimensions: $7 \times 6 \mathrm{~cm}$ ) and the flask were placed inside a custom-built set-up for fixing the light source and the sample container, and dissipating the excess heat. A concave mirror was placed in front of the PCB to maximize the light that irradiated the balloon. Light emitting diodes (LEDs) were purchased from Topbright.

\section{X-ray crystallography}

Single crystals of $\mathbf{2 c}$ and $4 \mathbf{a}$ of suitable quality for X-ray diffraction measurements were grown by slow diffusion of $n$-pentane into $\mathrm{CH}_{2} \mathrm{Cl}_{2}$ solutions of the crude product at $-18{ }^{\circ} \mathrm{C}$ for several weeks. One selected single crystal was mounted at the end of a quartz fiber in a random orientation, covered with perfluorinated oil (magic oil) (2c) or paratone oil (4a) on MiTeGen microMounts cryoloop and placed under a cold stream of nitrogen gas. Crystallographic measurements were carried out at $100 \mathrm{~K}$ on Bruker Smart APEX CCD (2c) or Bruker D8 Venture (4a) diffractometers, using graphite monochromated Mo K $\alpha$ radiation $(\lambda=0.71073 \AA$ ). A hemisphere of data was collected in each case based on $\omega$-scan or $\varphi$-scan runs. The diffraction frames were integrated using the program SAINT [67] and the integrated intensities were corrected for absorption with SADABS [68]. The structures were solved and developed by Patterson and Fourier methods [69]. All nonhydrogen atoms were refined with anisotropic displacement parameters. The hydrogen atoms were placed at idealized positions and treated as riding atoms. Each hydrogen atom was assigned an isotropic displacement parameter equal to 1.2-1.5 times the equivalent isotropic displacement parameter of its parent atom. For structure solving and refinement the SHELX97 [70], and Bruker APEX3 software package [71] were used. The structures were refined to $\mathrm{F}_{\mathrm{o}}{ }^{2}$, and all reflections were used in the least-squares calculations [70] CCDC-1991019 (2c) and
-1991018 (4a) contain the supplementary crystallographic data for this paper. These data can be obtained free of charge from the Cambridge Crystallographic Data Centre via http:// www.ccdc.cam.ac.uk/data_request/cif.

\section{General synthesis of the 4-((Z)-arylidene)-2- $((E)$-styryl)-5(4H)-oxazolones $\mathbf{2 a - j}$}

The oxazolones $\mathbf{2} \mathbf{a}-\mathbf{j}$ were prepared following the general Erlenmeyer-Plöchl method reported in the literature [42-48]. To a solution of $N$-cinnamoylglycine $(1,1.000 \mathrm{mg}, 4.87 \mathrm{mmol})$ in acetic anhydride $(5 \mathrm{~mL})$, sodium acetate $(400 \mathrm{mg}, 4.87 \mathrm{mmol})$ and the corresponding benzaldehyde $(4.87 \mathrm{mmol})$ were added. The resulting suspension was heated to $110^{\circ} \mathrm{C}$ for $2 \mathrm{~h}$ and then allowed to cool to room temperature. The resulting deep yellow precipitate was stirred with ethanol $(25 \mathrm{~mL})$, filtered off, washed with water $(20 \mathrm{~mL})$, additional ethanol $(25 \mathrm{~mL})$ and diethyl ether $(20 \mathrm{~mL})$, and dried by suction. The resulting yellow solid was characterized as the corresponding oxazolone $\mathbf{2 a}-\mathbf{j}$.

Characterization of 4-( $(Z)$-4-fluorobenzylidene)-2-( $(E)$ styryl)oxazol-5(4H)-one (2b): Following the general procedure, 1 (1000 mg, $4.87 \mathrm{mmol})$ was reacted with 4-fluorobenzaldehyde $(0.513 \mathrm{~mL}, 4.87 \mathrm{mmol})$ and sodium acetate $(400 \mathrm{mg}$, $4.87 \mathrm{mmol})$ in acetic anhydride $(5 \mathrm{~mL})$ to give $\mathbf{2 b}$ as a yellow solid. Obtained: $577 \mathrm{mg}, 1.969 \mathrm{mmol}, 40 \%$ yield. ${ }^{1} \mathrm{H}$ NMR (300.13 MHz, $\left.\mathrm{CDCl}_{3}\right) \delta 8.16\left(\mathrm{~m}, 2 \mathrm{H}, \mathrm{H}_{2}, \mathrm{H}_{6^{\prime}}, \mathrm{C}_{6} \mathrm{H}_{4} \mathrm{~F}\right), 7.70$ (d, $\left.J=16.2 \mathrm{~Hz}, 1 \mathrm{H}, \mathrm{H}_{\beta}\right), 7.59\left(\mathrm{~m}, 2 \mathrm{H}, \mathrm{H}_{\mathrm{o}}, \mathrm{C}_{6} \mathrm{H}_{5}\right), 7.49-7.38(\mathrm{~m}$, $\left.3 \mathrm{H}, \mathrm{H}_{\mathrm{m}}, \mathrm{H}_{\mathrm{p}}, \mathrm{C}_{6} \mathrm{H}_{5}\right), 7.22-7.08\left(\mathrm{~m}, 3 \mathrm{H}, \mathrm{H}_{3^{\prime}}, \mathrm{H}_{5^{\prime}}, \mathrm{C}_{6} \mathrm{H}_{4} \mathrm{~F}, \mathrm{H}_{\mathrm{vin}}\right)$, $6.81\left(\mathrm{~d}, J=16.2 \mathrm{~Hz}, 1 \mathrm{H}, \mathrm{H}_{\alpha}\right) ;{ }^{13} \mathrm{C}\left\{{ }^{1} \mathrm{H}\right\} \mathrm{NMR}(75.47 \mathrm{MHz}$, $\left.\mathrm{CDCl}_{3}\right) \delta 167.3(\mathrm{~s}, \mathrm{C}=\mathrm{O}), 164.3\left(\mathrm{~d},{ }^{1} J_{\mathrm{CF}}=255.1 \mathrm{~Hz}, \mathrm{C}-\mathrm{F}\right.$, $\left.\mathrm{C}_{6} \mathrm{H}_{4} \mathrm{~F}\right), 163.6(\mathrm{~s}, \mathrm{C}=\mathrm{N}), 144.2\left(\mathrm{~s}, \mathrm{CH},=\mathrm{C}_{\beta}\right), 134.7\left(\mathrm{~d},{ }^{3} J_{\mathrm{CF}}=\right.$ $8.5 \mathrm{~Hz}, \mathrm{CH}, \mathrm{C}_{6} \mathrm{H}_{4} \mathrm{~F}$ ), 133.3 (s, =C), 133.3 (s, C, $\mathrm{C}_{\mathrm{ipso}}, \mathrm{C}_{6} \mathrm{H}_{5}$ ), 131.0 (s, CH, $\mathrm{C}_{\mathrm{p}}, \mathrm{C}_{6} \mathrm{H}_{5}$ ), 130.1 (d, ${ }^{4} J_{\mathrm{CF}}=3.4 \mathrm{~Hz}, \mathrm{C}, \mathrm{C}_{6} \mathrm{H}_{4} \mathrm{~F}$ ), $129.9\left(\mathrm{~d},{ }^{5} J_{\mathrm{CF}}=1.6 \mathrm{~Hz},=\mathrm{CH}, \mathrm{C}_{\mathrm{vin}}\right), 129.3\left(\mathrm{~s}, \mathrm{CH}, \mathrm{C}_{\mathrm{m}}, \mathrm{C}_{6} \mathrm{H}_{5}\right)$, $128.3\left(\mathrm{~s}, \mathrm{CH}, \mathrm{C}_{\mathrm{o}}, \mathrm{C}_{6} \mathrm{H}_{5}\right), 116.3\left(\mathrm{~d},{ }^{2} J_{\mathrm{CF}}=22.3 \mathrm{~Hz}, \mathrm{CH}\right.$, $\left.\mathrm{C}_{6} \mathrm{H}_{4} \mathrm{~F}\right), 113.4\left(\mathrm{~s}, \mathrm{CH},=\mathrm{C}_{\alpha}\right) ;{ }^{19} \mathrm{~F}$ NMR $\left(282.40 \mathrm{MHz}, \mathrm{CDCl}_{3}\right) \delta$ -106.71 (tt, $J=8.5,5.6 \mathrm{~Hz}$ ); HRMS $\left(\mathrm{ESI}^{+}\right) \mathrm{m} / z$ : $[\mathrm{M}+\mathrm{Na}]^{+}$: calcd for $\mathrm{C}_{18} \mathrm{H}_{12} \mathrm{FNNaO}_{2}, 316.0750$; found, 316.0719; IR ( $v$, $\left.\mathrm{cm}^{-1}\right): 1782(v \mathrm{C}=\mathrm{O}), 1655(v \mathrm{C}=\mathrm{N})$.

\section{General synthesis of the ortho-palladated derivatives $\mathbf{3 a - f}, \mathbf{3 h}-\mathbf{j}$}

In a similar manner as described in [30], to a solution of the oxazolones $\mathbf{2 a}-\mathbf{j}$ in $\mathrm{CF}_{3} \mathrm{CO}_{2} \mathrm{H}(8 \mathrm{~mL})$, the stoichiometric amount of $\mathrm{Pd}(\mathrm{OAc})_{2}$ (1:1 molar ratio) was added. The resulting mixture was heated at $75{ }^{\circ} \mathrm{C}$ for $2 \mathrm{~h}$ with stirring. During this time, the color of the suspension changed from yellow to reddish, and an increase in the amount of precipitated red solid was evident. After the reaction time the mixture was cooled to room temperature and distilled water $(10 \mathrm{~mL})$ was added. The 
resulting reddish solid was filtered off, washed with additional portions of distilled water until the smell of the trifluoroacetic acid disappeared (in general $3 \times 10 \mathrm{~mL}$ was sufficient, but a larger amount could be necessary), dried in vacuo and characterized as the orthopalladated dimers $\mathbf{3 a}-\mathbf{f}$ and $\mathbf{3 h}-\mathbf{j}$.

Characterization of ortho-palladated complex 3b: Following the general method, oxazolone $\mathbf{2 b}(200 \mathrm{mg}, 0.683 \mathrm{mmol})$ was reacted with $\mathrm{Pd}(\mathrm{OAc})_{2}(153 \mathrm{mg}, 0.683 \mathrm{mmol})$ in $\mathrm{CF}_{3} \mathrm{CO}_{2} \mathrm{H}$ $(8 \mathrm{~mL})$ to give $\mathbf{3 b}$ as a reddish solid. Obtained: $332 \mathrm{mg}$, $0.324 \mathrm{mmol}, 95 \%$ yield. ${ }^{1} \mathrm{H} \mathrm{NMR}\left(300.13 \mathrm{MHz}, \mathrm{CDCl}_{3}\right) \delta 7.57$ $\left(\mathrm{m}, 2 \mathrm{H}, \mathrm{H}_{\mathrm{o}}, \mathrm{C}_{6} \mathrm{H}_{5}\right), 7.49\left(\mathrm{~d}, J=16.1 \mathrm{~Hz}, 1 \mathrm{H}, \mathrm{H}_{\beta}\right), 7.49-7.39$ (m, 3H, $\mathrm{H}_{\mathrm{m}}, \mathrm{H}_{\mathrm{p}}, \mathrm{C}_{6} \mathrm{H}_{5}$ ), 7.30 (s, 1H, $\mathrm{H}_{\mathrm{vin}}$ ), 7.21 (dd, J = 8.4, 6.1 $\left.\mathrm{Hz}, 1 \mathrm{H}, \mathrm{H}_{2}, \mathrm{C}_{6} \mathrm{H}_{3} \mathrm{~F}\right), 7.04$ (d, $\left.J=15.9 \mathrm{~Hz}, 1 \mathrm{H}, \mathrm{H}_{\alpha}\right), 6.87$ (td, $J=$ 7.9, $\left.2.4 \mathrm{~Hz}, 1 \mathrm{H}, \mathrm{H}_{3}, \mathrm{C}_{6} \mathrm{H}_{3} \mathrm{~F}\right), 6.81$ (dd, $J=10.1,2.4 \mathrm{~Hz}, 1 \mathrm{H}$, $\left.\mathrm{H}_{5}, \mathrm{C}_{6} \mathrm{H}_{3} \mathrm{~F}\right) ;{ }^{13} \mathrm{C}\left\{{ }^{1} \mathrm{H}\right\}$ NMR $\left(75.47 \mathrm{MHz}, \mathrm{CDCl}_{3}\right) \delta 166.2(\mathrm{q}$, $\left.{ }^{2} J_{\mathrm{CF}}=39.1 \mathrm{~Hz}, \mathrm{C}, \mathrm{CO}_{2} \mathrm{CF}_{3}\right), 165.7(\mathrm{~s}, \mathrm{C}=\mathrm{N}), 161.8\left(\mathrm{~d},{ }^{1} J_{\mathrm{CF}}=\right.$ $247.1 \mathrm{~Hz}, \mathrm{C}-\mathrm{F}, \mathrm{C}_{6} \mathrm{H}_{3} \mathrm{~F}$ ), 160.0 ( $\mathrm{s}, \mathrm{C}=\mathrm{O}$ ), 149.2 (s, CH, = $\mathrm{C}_{\beta}$ ), $137.0\left(\mathrm{~d},{ }^{3} J_{\mathrm{CF}}=6.8 \mathrm{~Hz}, \mathrm{C}, \mathrm{C}_{6} \mathrm{H}_{3} \mathrm{~F}\right), 135.4\left(\mathrm{~s}, \mathrm{CH},=\mathrm{C}_{\mathrm{vin}}\right), 134.1$ $\left(\mathrm{d},{ }^{3} J_{\mathrm{CF}}=8.7 \mathrm{~Hz}, \mathrm{CH}, \mathrm{C}_{6} \mathrm{H}_{3} \mathrm{~F}\right), 133.5\left(\mathrm{~s}, \mathrm{C}, \mathrm{C}_{\mathrm{ipso}}, \mathrm{C}_{6} \mathrm{H}_{5}\right), 132.5$ (s, $\mathrm{CH}, \mathrm{C}_{\mathrm{p}}, \mathrm{C}_{6} \mathrm{H}_{5}$ ), 129.3 (s, CH, $\mathrm{C}_{\mathrm{o}}, \mathrm{C}_{6} \mathrm{H}_{5}$ ), 129.2 (s, $\mathrm{CH}, \mathrm{C}_{\mathrm{m}}$, $\left.\mathrm{C}_{6} \mathrm{H}_{5}\right), 126.2\left(\mathrm{~d},{ }^{4} J_{\mathrm{CF}}=2.8 \mathrm{~Hz}, \mathrm{C}, \mathrm{C}_{6} \mathrm{H}_{3} \mathrm{~F}\right), 122.0\left(\mathrm{~d},{ }^{6} J_{\mathrm{CF}}=\right.$ $2.6 \mathrm{~Hz},=\mathrm{C}), 120.5\left(\mathrm{~d},{ }^{2} J_{\mathrm{CF}}=22.3 \mathrm{~Hz}, \mathrm{CH}, \mathrm{C}_{6} \mathrm{H}_{3} \mathrm{~F}\right), 115.0$ (q, $\left.{ }^{1} J_{\mathrm{CF}}=288.4 \mathrm{~Hz}, \mathrm{C}, \mathrm{CF}_{3}\right), 113.5\left(\mathrm{~d},{ }^{2} J_{\mathrm{CF}}=23.1 \mathrm{~Hz}, \mathrm{CH}\right.$, $\left.\mathrm{C}_{6} \mathrm{H}_{3} \mathrm{~F}\right), 109.8\left(\mathrm{~s}, \mathrm{CH},=\mathrm{C}_{\alpha}\right) ;{ }^{19} \mathrm{~F}$ NMR $\left(282.40 \mathrm{MHz}, \mathrm{CDCl}_{3}\right) \delta$ $-74.77\left(\mathrm{~s}, \mathrm{CF}_{3}\right),-102.95\left(\mathrm{ddd}, J=10.2,7.5,6.0 \mathrm{~Hz}, \mathrm{~F}_{4}\right.$, $\mathrm{C}_{6} \mathrm{H}_{3} \mathrm{~F}$ ). HRMS (ESI+) $\mathrm{m} / \mathrm{z}$ : $\left[\mathrm{M}-\mathrm{COOCF}_{3}+\mathrm{CH}_{3} \mathrm{O}+\mathrm{Na}\right]^{+}$ calcd. for, $\mathrm{C}_{38} \mathrm{H}_{28} \mathrm{~F}_{2} \mathrm{~N}_{2} \mathrm{NaO}_{6} \mathrm{Pd}_{2}$ 882.9887; found, 882.9908; IR $\left(v, \mathrm{~cm}^{-1}\right): 1791(v \mathrm{C}=\mathrm{O}), 1653(\mathrm{vC}=\mathrm{N}), 1190\left(\mathrm{vCF}_{3}\right)$.

\section{General synthesis of the ortho-palladated cyclobutanes $\mathbf{4 a - f}, \mathbf{4 h}-\mathbf{j}$}

The ortho-palladated dimers $\mathbf{3}$ (amount specified in each case) were suspended in $\mathrm{CH}_{2} \mathrm{Cl}_{2}(20-40 \mathrm{~mL})$. The suspension was stirred at room temperature while irradiating with blue light (465 nm, see 'irradiation setup' section) for $48 \mathrm{~h}$. As a rule of thumb, the initial suspension dissolved as the reaction progressed, and a clear solution was obtained after the reaction time. In a few cases some evidence of decomposition (presence of black $\mathrm{Pd}^{0}$ ) was observed. This was removed by filtration through a bed of Celite ${ }^{\circledR}$. The resulting clear solution was evaporated to dryness to afford the corresponding ortho-palladated cyclobutanes $\mathbf{4}$ as deep yellow solids.

Characterization of ortho-palladated cyclobutane $4 \mathrm{~b}$ : Following the general method, ortho-palladated $\mathbf{3 b}$ (250 mg, $0.244 \mathrm{mmol})$ in $\mathrm{CH}_{2} \mathrm{Cl}_{2}(20 \mathrm{~mL})$ was irradiated with blue light $(465 \mathrm{~nm})$ for $48 \mathrm{~h}$ to give ortho-palladated cyclobutane $\mathbf{4 b}$ as a yellow solid. Obtained: $228 \mathrm{mg}, 0.223 \mathrm{mmol}, 91 \%$ yield. ${ }^{1} \mathrm{H}$ NMR $\left(300.13 \mathrm{MHz}, \mathrm{CDCl}_{3}\right) \delta 7.73\left(\mathrm{~d}, J=16.0 \mathrm{~Hz}, 1 \mathrm{H}, \mathrm{H}_{\beta}\right)$, $7.67\left(\mathrm{~m}, 2 \mathrm{H}, \mathrm{H}_{\mathrm{o}}, \mathrm{C}_{6} \mathrm{H}_{5}\right), 7.57\left(\mathrm{~d}, J=16.0 \mathrm{~Hz}, 1 \mathrm{H}, \mathrm{H}_{\alpha}\right)$,
7.53-7.43 (m, 3H, $\left.\mathrm{H}_{\mathrm{m}}, \mathrm{H}_{\mathrm{p}}, \mathrm{C}_{6} \mathrm{H}_{5}\right), 6.86(\mathrm{dd}, J=9.3,2.4 \mathrm{~Hz}$, $\left.1 \mathrm{H}, \mathrm{H}_{5^{\prime}}, \mathrm{C}_{6} \mathrm{H}_{3} \mathrm{~F}\right), 6.78\left(\mathrm{dd}, J=8.3,5.6 \mathrm{~Hz}, 1 \mathrm{H}, \mathrm{H}_{2}, \mathrm{C}_{6} \mathrm{H}_{3} \mathrm{~F}\right)$, $6.71\left(\mathrm{td}, J=8.0,2.4 \mathrm{~Hz}, 1 \mathrm{H}, \mathrm{H}_{3^{\prime}}, \mathrm{C}_{6} \mathrm{H}_{3} \mathrm{~F}\right), 4.95(\mathrm{~s}, 1 \mathrm{H}, \mathrm{CH}$ cyclobutane); ${ }^{13} \mathrm{C}\left\{{ }^{1} \mathrm{H}\right\}$ NMR $\left(75.47 \mathrm{MHz}, \mathrm{CDCl}_{3}\right) \delta 172.2$ (s, $\mathrm{C}=\mathrm{O}), 168.9\left(\mathrm{~s}, \mathrm{C}, \mathrm{C}_{2}, \mathrm{C}=\mathrm{N}\right), 167.2\left(\mathrm{q},{ }^{2} J_{\mathrm{CF}}=36.4 \mathrm{~Hz}, \mathrm{C}\right.$, $\left.\mathrm{CO}_{2} \mathrm{CF}_{3}\right), 160.1\left(\mathrm{~d},{ }^{1} J_{\mathrm{CF}}=253.7 \mathrm{~Hz}, \mathrm{C}-\mathrm{F}, \mathrm{C}_{6} \mathrm{H}_{3} \mathrm{~F}\right), 151.2(\mathrm{~s}$, $\left.\mathrm{CH},=\mathrm{C}_{\beta}\right), 137.4\left(\mathrm{~d},{ }^{3} J_{\mathrm{CF}}=6.2 \mathrm{~Hz}, \mathrm{C}, \mathrm{C}_{6} \mathrm{H}_{3} \mathrm{~F}\right), 133.3(\mathrm{~s}, \mathrm{C}$, $\left.\mathrm{C}_{\mathrm{ipso}}, \mathrm{C}_{6} \mathrm{H}_{5}\right), 133.0\left(\mathrm{~s}, \mathrm{CH}, \mathrm{C}_{\mathrm{p}}, \mathrm{C}_{6} \mathrm{H}_{5}\right), 130.0\left(\mathrm{~d},{ }^{3} J_{\mathrm{CF}}=8.1 \mathrm{~Hz}\right.$, $\mathrm{CH}, \mathrm{C}_{6} \mathrm{H}_{3} \mathrm{~F}$ ), 129.6 (s, CH, $\mathrm{C}_{\mathrm{m}}, \mathrm{C}_{6} \mathrm{H}_{5}$ ), 129.6 (s, CH, $\mathrm{C}_{\mathrm{o}}$, $\left.\mathrm{C}_{6} \mathrm{H}_{5}\right), 123.5\left(\mathrm{~d},{ }^{4} J_{\mathrm{CF}}=2.9 \mathrm{~Hz}, \mathrm{C}, \mathrm{C}_{6} \mathrm{H}_{3} \mathrm{~F}\right), 120.5\left(\mathrm{~d},{ }^{2} J_{\mathrm{CF}}=\right.$ $\left.22.1 \mathrm{~Hz}, \mathrm{CH}, \mathrm{C}_{6} \mathrm{H}_{3} \mathrm{~F}\right), 115.3\left(\mathrm{q},{ }^{1} J_{\mathrm{CF}}=287.5 \mathrm{~Hz}, \mathrm{C}, \mathrm{CF}_{3}\right) 113.2$ $\left(\mathrm{d},{ }^{2} J_{\mathrm{CF}}=22.3 \mathrm{~Hz}, \mathrm{CH}, \mathrm{C}_{6} \mathrm{H}_{3} \mathrm{~F}\right), 110.9\left(\mathrm{~s}, \mathrm{CH},=\mathrm{C}_{\alpha}\right), 69.0(\mathrm{~s}, \mathrm{C}$, cyclobutane), 59.5 (s, CH, cyclobutane); ${ }^{19} \mathrm{~F}$ NMR $(282.40$ $\mathrm{MHz}, \mathrm{CDCl}_{3}$ ) $\delta-74.60\left(\mathrm{~s}, 3 \mathrm{~F}, \mathrm{CF}_{3}\right.$ ), -110.53 (ddd, $J=9.0,8.0$, $5.7 \mathrm{~Hz}, 1 \mathrm{~F}, \mathrm{~F}_{\mathrm{ar}}$ ); anal. calcd for $\mathrm{C}_{40} \mathrm{H}_{22} \mathrm{~F}_{8} \mathrm{~N}_{2} \mathrm{O}_{8} \mathrm{Pd}_{2}$ : C, 46.94; $\mathrm{H}, 2.17$; N, 2.74; found: C, 46.81; H, 2.28; N, 2.94; IR ( $v$, $\left.\mathrm{cm}^{-1}\right): 1836(v \mathrm{C}=\mathrm{O}), 1652(v \mathrm{C}=\mathrm{N}), 1191\left(v^{2} F_{3}\right)$.

\section{General synthesis of the ortho-methoxycar- bonylated 1,3-diaminotruxillics 5}

The ortho-palladated cyclobutanes $\mathbf{4}(\mathbf{4 b}, \mathbf{4 d}, \mathbf{4 f}, \mathbf{4 h}, \mathbf{4 j})$ were dissolved in a mixture of methanol and acetonitrile (1:3 ratio $\mathrm{MeOH} / \mathrm{NCMe}$ ). The solution was stirred under a $\mathrm{CO}$ atmosphere ( $1 \mathrm{~atm}$; balloon) for $16 \mathrm{~h}$. During the reaction time the decomposition of the organopalladium complex was evident as black $\mathrm{Pd}^{0}$ was formed. After the reaction time the resulting black suspension was filtered through a Celite ${ }^{\circledR}$ pad to give a yellow solution. The Celite ${ }^{\circledR}$ was washed with additional $\mathrm{NCMe}(10 \mathrm{~mL})$ and the combined solutions were evaporated to dryness to afford the corresponding ortho-methoxycarbonylated 1,3-diaminotruxillic derivatives $(\mathbf{5 b}, \mathbf{5 d}, \mathbf{5 f}, \mathbf{5 h}, \mathbf{5 j})$ as yellow solids.

Characterization of dimethyl 1,3-dicinnamamido-2,4-bis(4fluoro-2-(methoxycarbonyl)phenyl)cyclobutane-1,3-dicarboxylate (5b): Following the general method, a solution of the ortho-palladated cyclobutane $4 \mathbf{b}(150 \mathrm{mg}, 0.146 \mathrm{mmol})$ in a mixture of methanol $(5 \mathrm{~mL})$ and NCMe $(15 \mathrm{~mL})$ was stirred under a $\mathrm{CO}$ atmosphere $(1 \mathrm{~atm})$ for $16 \mathrm{~h}$ to give the truxillic cyclobutane derivative $\mathbf{5 b}$ as a pale yellow solid. Obtained: $95 \mathrm{mg}, 0.124 \mathrm{mmol}, 84 \%$ yield. ${ }^{1} \mathrm{H}$ NMR (400.13 $\mathrm{MHz}$, $\left.\mathrm{CDCl}_{3}\right) \delta 7.70\left(\mathrm{dd}, J=8.9,5.5 \mathrm{~Hz}, 1 \mathrm{H}, \mathrm{H}_{6}, \mathrm{C}_{6} \mathrm{H}_{3} \mathrm{~F}\right), 7.52-7.47$ (m, 2H, $\mathrm{H}_{\mathrm{o}}, \mathrm{C}_{6} \mathrm{H}_{5}$ ), 7.42-7.36 (m, 6H, NH, H $, \mathrm{C}_{6} \mathrm{H}_{3} \mathrm{~F}, \mathrm{H}_{\mathrm{m}}, \mathrm{H}_{\mathrm{p}}$, $\left.\mathrm{C}_{6} \mathrm{H}_{5}, \mathrm{H}_{\beta}\right), 7.09\left(\mathrm{~m}, 1 \mathrm{H}, \mathrm{H}_{5}, \mathrm{C}_{6} \mathrm{H}_{3} \mathrm{~F}\right), 6.40(\mathrm{~d}, J=15.7 \mathrm{~Hz}, 1 \mathrm{H}$, $\mathrm{H}_{\alpha}$ ), 6.01 (s, 1H, cyclobutane), 4.00 (s, broad, 3H, OMe, $\mathrm{CO}_{2} \mathrm{Me}$ cyclobutane), 3.88 (s, $3 \mathrm{H}, \mathrm{OMe}, \mathrm{Ar}-\mathrm{CO}_{2} \mathrm{Me}$ ); ${ }^{13} \mathrm{C}\left\{{ }^{1} \mathrm{H}\right\}$ NMR (75.47 MHz, $\mathrm{CDCl}_{3}$ ) $\delta 172.3$ (s, $\mathrm{CO}_{2} \mathrm{Me}$ cyclobutane), $167.9\left(\mathrm{~s}, \mathrm{Ar}-\mathrm{CO}_{2} \mathrm{Me}\right), 166.6(\mathrm{~s}, \mathrm{NHC}=\mathrm{O}), 161.3\left(\mathrm{~d},{ }^{1} J_{\mathrm{CF}}=\right.$ $\left.248.0 \mathrm{~Hz}, \mathrm{C}-\mathrm{F}, \mathrm{C}_{6} \mathrm{H}_{3} \mathrm{~F}\right), 142.8\left(\mathrm{~s}, \mathrm{CH},=\mathrm{C}_{\beta}\right), 134.4\left(\mathrm{~s}, \mathrm{C}, \mathrm{C}_{\mathrm{ipso}}\right.$, $\mathrm{Ph}), 133.6\left(\mathrm{~d},{ }^{3} J_{\mathrm{CF}}=7.0 \mathrm{~Hz}, \mathrm{C}, \mathrm{C}_{6} \mathrm{H}_{3} \mathrm{~F}\right), 131.3\left(\mathrm{~d},{ }^{3} J_{\mathrm{CF}}=\right.$ $7.8 \mathrm{~Hz}, \mathrm{CH}, \mathrm{C}_{6} \mathrm{H}_{3} \mathrm{~F}$ ), 130.4 (s, CH, C, $\mathrm{Ph}$ ), 129.2 (s, C, 
$\mathrm{C}_{6} \mathrm{H}_{3} \mathrm{~F}$ ), 129.0 (s, $\mathrm{CH}, \mathrm{C}_{\mathrm{m}}, \mathrm{Ph}$ ), 128.2 (s, CH, $\mathrm{C}_{\mathrm{o}}, \mathrm{Ph}$ ), 119.7 (s, $\left.\mathrm{CH},=\mathrm{C}_{\alpha}\right), 118.4\left(\mathrm{~d},{ }^{2} J_{\mathrm{CF}}=22.0 \mathrm{~Hz}, \mathrm{CH}, \mathrm{C}_{6} \mathrm{H}_{3} \mathrm{~F}\right), 117.2(\mathrm{~d}$, $\left.{ }^{2} J_{\mathrm{CF}}=23.0 \mathrm{~Hz}, \mathrm{CH}, \mathrm{C}_{6} \mathrm{H}_{3} \mathrm{~F}\right), 65.8(\mathrm{~s}, \mathrm{C}$, cyclobutane), $53.9(\mathrm{~s}$, $\mathrm{CH}, \mathrm{OMe}, \mathrm{CO}_{2} \mathrm{Me}$ cyclobutane), 52.7 (s, $\mathrm{CH}, \mathrm{OMe}$, Ar- $\mathrm{CO}_{2} \mathrm{Me}$ ), 48.2 (s, $\mathrm{CH}$, cyclobutane); ${ }^{19} \mathrm{~F}$ NMR (282.40 $\mathrm{MHz}, \mathrm{CDCl}_{3}$ ) $\delta-113.89$ (pseudo dt, $J=8.6,5.8 \mathrm{~Hz}$ ). HRMS $\left(\mathrm{ESI}^{+}\right) \mathrm{m} / \mathrm{z}:[\mathrm{M}+\mathrm{Na}]^{+}$calcd. for $\mathrm{C}_{42} \mathrm{H}_{36} \mathrm{~F}_{2} \mathrm{~N}_{2} \mathrm{NaO}_{10}, 789.2236$;

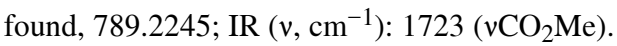

\section{Supporting Information}

\section{Supporting Information File 1}

Complete experimental section; copies of NMR spectra of 2 and 3.

[https://www.beilstein-journals.org/bjoc/content/ supplementary/1860-5397-16-98-S1.pdf]

\section{Supporting Information File 2}

Copies on NMR spectra of compounds $\mathbf{4}$ and $\mathbf{5}$, crystallographic tables of compounds $\mathbf{2 c}$ and $\mathbf{4 a}$. [https://www.beilstein-journals.org/bjoc/content/ supplementary/1860-5397-16-98-S2.pdf]

\section{Funding}

The authors thanks Gobierno de Aragón (Spain) for financial funding through project LMP144_18 (Programa Operativo FEDER Aragón 2014-2020, "Construyendo Europa desde Aragón") and research group Aminoacidos y Peptidos (E19_20R). A.P. is grateful to Babeș-Bolyai University for the grant Advanced Fellowship STAR-UBB. The financial support of the Romanian Ministry of Education and Research through the grant Grant PN-III-P4-ID-PCCF-2016-0088-P2 is highly acknowledged.

\section{ORCID ${ }^{\circledR}$ iDs}

Esteban P. Urriolabeitia - https://orcid.org/0000-0001-9779-5820 Alexandra Pop - https://orcid.org/0000-0002-2355-3682 Cristian Silvestru - https://orcid.org/0000-0001-5124-9525 Eduardo Laga - https://orcid.org/0000-0003-1882-2558 Ana I. Jiménez - https://orcid.org/0000-0001-8057-4861

\section{References}

1. Liebermann, C.; Giesel, F. Ber. Dtsch. Chem. Ges. 1888, 21, 3196-3202. doi:10.1002/cber.188802102188

2. Nakamura, M.; Chi, Y.-M.; Yan, W.-M.; Yonezawa, A.; Nakasugi, Y.; Yoshizawa, T.; Hashimoto, F.; Kinjo, J.; Nohara, T.; Sakurada, S. Planta Med. 2001, 67, 114-117. doi:10.1055/s-2001-11512

3. Chi, Y.-M.; Nakamura, M.; Yoshizawa, T.; Zhao, X.-Y.; Yan, W.-M.; Hashimoto, F.; Kinjo, J.; Nohara, T.; Sakurada, S. Biol. Pharm. Bull. 2005, 28, 1776-1778. doi:10.1248/bpb.28.1776
4. Chi, Y.-M.; Nakamura, M.; Zhao, X.-Y.; Yoshizawa, T.; Yan, W.-M.; Hashimoto, F.; Kinjo, J.; Nohara, T.; Sakurada, S. Biol. Pharm. Bull. 2006, 29, 489-493. doi:10.1248/bpb.29.489

5. Chi, Y.-M.; Nakamura, M.; Zhao, X.-Y.; Yoshizawa, T.; Yan, W.-M.; Hashimoto, F.; Kinjo, J.; Nohara, T.; Sakurada, S. Biol. Pharm. Bull. 2006, 29, 580-584. doi:10.1248/bpb.29.580

6. Rupp, M.; Schroeter, T.; Steri, R.; Zettl, H.; Proschak, E.; Hansen, K.; Rau, O.; Schwarz, O.; Müller-Kuhrt, L.; Schubert-Zsilavecz, M.; Müller, K.-R.; Schneider, G. ChemMedChem 2010, 5, 191-194. doi:10.1002/cmdc.200900469

7. Berger, W. T.; Ralph, B. P.; Kaczocha, M.; Sun, J.; Balius, T. E.; Rizzo, R. C.; Haj-Dahmane, S.; Ojima, I.; Deutsch, D. G. PLoS One 2012, 7, e50968. doi:10.1371/journal.pone.0050968

8. Yan, S.; Elmes, M. W.; Tong, S.; Hu, K.; Awwa, M.; Teng, G. Y. H.; Jing, Y.; Freitag, M.; Gan, Q.; Clement, T.; Wei, L.; Sweeney, J. M.; Joseph, O. M.; Che, J.; Carbonetti, G. S.; Wang, L.; Bogdan, D. M.; Falcone, J.; Smietalo, N.; Zhou, Y.; Ralph, B.; Hsu, H.-C.; Li, H.; Rizzo, R. C.; Deutsch, D. G.; Kaczocha, M.; Ojima, I. Eur. J. Med. Chem. 2018, 154, 233-252. doi:10.1016/j.ejmech.2018.04.050

9. Kaczocha, M.; Rebecchi, M. J.; Ralph, B. P.; Teng, Y.-H. G.; Berger, W. T.; Galbavy, W.; Elmes, M. W.; Glaser, S. T.; Wang, L.; Rizzo, R. C.; Deutsch, D. G.; Ojima, I. PLoS One 2014, 9, e94200. doi:10.1371/journal.pone.0094200

10. Ojima, I.; Deutsch, D.; Kaczocha, M.; Berger, W. T.; Rizzo, R.; Balius, T. E. Alpha and gamma-truxillic and derivatives and pharmaceutical compositions thereof. U.S. Patent US10213406 B2, July 4, 2019.

11. Kim, J.; Bogdan, D. M.; Elmes, M. W.; Awwa, M.; Yan, S.; Che, J.; Lee, G.; Deutsch, D. G.; Rizzo, R. C.; Kaczocha, M.; Ojima, I. PLoS One 2019, 14, e0218619. doi:10.1371/journal.pone.0218619

12. Priebe, A.; Hunke, M.; Tonello, R.; Sonawane, Y.; Berta, T.; Natarajan, A.; Bhuvanesh, N.; Pattabiraman, M.; Chandra, S. J. Pain Res. 2018, 11, 1075-1085. doi:10.2147/jpr.s161161

13. Yuan, X.; Lin, L.; Zhang, X.; Deng, S. Phytochem. Lett. 2014, 7, 137-142. doi:10.1016/j.phytol.2013.11.003

14. Matta, A.; Chammingkwan, P.; Singh, B. K.; Terano, M.; Kaneko, T.; Taniike, T. Appl. Catal., A 2018, 554, 80-87. doi:10.1016/j.apcata.2018.01.030

15. Wang, Z.; Miller, B.; Mabin, M.; Shahni, R.; Wang, Z. D.; Ugrinov, A.; Chu, Q. R. Sci. Rep. 2017, 7, 13704. doi:10.1038/s41598-017-13983-Z 16. Liu, Q.; Li, N.; Yuan, Y.; Lu, H.; Wu, X.; Zhou, C.; He, M.; Su, H.; Zhang, M.; Wang, J.; Wang, B.; Wang, Y.; Ma, D.; Ye, Y.; Weiss, H.-C.; Gesing, E. R. F.; Liao, J.; Wang, M.-W. J. Med. Chem. 2012, 55, 250-267. doi:10.1021/jm201150j

17. Chen, D.; Liao, J.; Li, N.; Zhou, C.; Liu, Q.; Wang, G.; Zhang, R.; Zhang, S.; Lin, L.; Chen, K.; Xie, X.; Nan, F.; Young, A. A.; Wang, M.-W. Proc. Natl. Acad. Sci. U. S. A. 2007, 104, 943-948. doi:10.1073/pnas.0610173104

18. de Graaf, C.; Donnelly, D.; Wootten, D.; Lau, J.; Sexton, P. M.; Miller, L. J.; Ahn, J.-M.; Liao, J.; Fletcher, M. M.; Yang, D.; Brown, A. J. H.; Zhou, C.; Deng, J.; Wang, M.-W. Pharmacol. Rev. 2016, 68, 954-1013. doi:10.1124/pr.115.011395

19. Poplata, S.; Tröster, A.; Zou, Y.-Q.; Bach, T. Chem. Rev. 2016, 116, 9748-9815. doi:10.1021/acs.chemrev.5b00723

20. Sokolova, A.; Pavlova, A.; Komarova, N.; Ardashov, O.; Shernyukov, A.; Gatilov, Y.; Yarovaya, O.; Tolstikova, T.; Salakhutdinov, N. Med. Chem. Res. 2016, 25, 1608-1615. doi:10.1007/s00044-016-1593-z 
21. Zhang, F.; Jia, Y. Tetrahedron 2009, 65, 6840-6843. doi:10.1016/j.tet.2009.06.068

22. Cohen, M. D.; Schmidt, G. M. J.; Sonntag, F. I. J. Chem. Soc. 1964, 2000. doi:10.1039/jr9640002000

23. Schmidt, G. M. J. Pure Appl. Chem. 1971, 27, 647-678. doi:10.1351/pac197127040647

24. Ramamurthy, V.; Venkatesan, K. Chem. Rev. 1987, 87, 433-481. doi:10.1021/cr00078a009

25. Pagire, S. K.; Hossain, A.; Traub, L.; Kerres, S.; Reiser, O. Chem. Commun. 2017, 53, 12072-12075. doi:10.1039/c7cc06710k

26. Lei, T.; Zhou, C.; Huang, M.-Y.; Zhao, L.-M.; Yang, B.; Ye, C.; Xiao, H.; Meng, Q.-Y.; Ramamurthy, V.; Tung, C.-H.; Wu, L.-Z. Angew. Chem., Int. Ed. 2017, 56, 15407-15410. doi:10.1002/anie.201708559

27. García-Montero, A.; Rodriguez, A. M.; Juan, A.; Velders, A. H.; Denisi, A.; Jiménez-Osés, G.; Gómez-Bengoa, E.; Cativiela, C.; Gómez, M. V.; Urriolabeitia, E. P. ACS Sustainable Chem. Eng. 2017, 5, 8370-8381. doi:10.1021/acssuschemeng.7b02140

28. Roiban, D.; Serrano, E.; Soler, T.; Grosu, I.; Cativiela, C.; Urriolabeitia, E. P. Chem. Commun. 2009, 4681. doi:10.1039/b907647f

29. Serrano, E.; Juan, A.; García-Montero, A.; Soler, T.; Jiménez-Márquez, F.; Cativiela, C.; Gomez, M. V.; Urriolabeitia, E. P. Chem. - Eur. J. 2016, 22, 144-152. doi:10.1002/chem.201503742

30. Carrera, C.; Denisi, A.; Cativiela, C.; Urriolabeitia, E. P. Eur. J. Inorg. Chem. 2019, 3481-3489. doi:10.1002/ejic.201900548

31. Ando, R.; Hama, H.; Yamamoto-Hino, M.; Mizuno, H.; Miyawaki, A. Proc. Natl. Acad. Sci. U. S. A. 2002, 99, 12651-12656. doi:10.1073/pnas.202320599

32. Mizuno, H.; Mal, T. K.; Tong, K. I.; Ando, R.; Furuta, T.; Ikura, M.; Miyawaki, A. Mol. Cell 2003, 12, 1051-1058. doi:10.1016/s1097-2765(03)00393-9

33. He, X.; Bell, A. F.; Tonge, P. J. Org. Lett. 2002, 4, 1523-1526. doi:10.1021/ol0200403

34. Nienhaus, K.; Nienhaus, G. U.; Wiedenmann, J.; Nar, H. Proc. Natl. Acad. Sci. U. S. A. 2005, 102, 9156-9159. doi:10.1073/pnas.0501874102

35. Adam, V.; Lelimousin, M.; Boehme, S.; Desfonds, G.; Nienhaus, K.; Field, M. J.; Wiedenmann, J.; McSweeney, S.; Nienhaus, G. U.; Bourgeois, D. Proc. Natl. Acad. Sci. U. S. A. 2008, 105, 18343-18348. doi:10.1073/pnas.0805949105

36. Chuang, W.-T.; Chen, B.-S.; Chen, K.-Y.; Hsieh, C.-C.; Chou, P.-T. Chem. Commun. 2009, 6982. doi:10.1039/b908542d

37. Yampolsky, I. V.; Kislukhin, A. A.; Amatov, T. T.; Shcherbo, D.; Potapov, V. K.; Lukyanov, S.; Lukyanov, K. A. Bioorg. Chem. 2008, 36, 96-104. doi:10.1016/j.bioorg.2007.12.003

38. Li, X.; Chung, L. W.; Mizuno, H.; Miyawaki, A.; Morokuma, K. J. Phys. Chem. B 2010, 114, 16666-16675. doi:10.1021/jp1101779

39. Yale, H. L. J. Med. Chem. 1958, 1, 121-133. doi:10.1021/jm50003a001

40. Wang, J.; Sánchez-Roselló, M.; Aceña, J. L.; del Pozo, C.; Sorochinsky, A. E.; Fustero, S.; Soloshonok, V. A.; Liu, H. Chem. Rev. 2014, 114, 2432-2506. doi:10.1021/cr4002879

41. Kokotos, G.; Hsu, Y.-H.; Burke, J. E.; Baskakis, C.; Kokotos, C. G.; Magrioti, V.; Dennis, E. A. J. Med. Chem. 2010, 53, 3602-3610. doi:10.1021/jm901872v

42. Plöchl, J. Ber. Dtsch. Chem. Ges. 1883, 16, 2815-2825. doi:10.1002/cber.188301602235

43. Plöchl, J. Ber. Dtsch. Chem. Ges. 1884, 17, 1616-1624. doi:10.1002/cber.18840170215
44. Erlenmeyer, E., Jr. Justus Liebigs Ann. Chem. 1893, 275, 1-8. doi:10.1002/jlac.18932750102

45. Carter, H. E. Org. React. 1946, 3, 198.

46. Filler, R. Recent Advances in Oxazolone Chemistry. In Advances in Heterocyclic Chemistry; Katrizky, A. R., Ed.; Academic Press: New York, NY, USA, 1965; pp 75-106. doi:10.1016/s0065-2725(08)60875-2

47. Rao, Y. S.; Filler, R. Synthesis 1975, 749-764. doi:10.1055/s-1975-23919

48. Rao, Y. S.; Filler, R. Oxazolones. In Chemistry of Heterocyclic Compounds; Turchi, I. J., Ed.; John Wiley \& Sons: New York, NY, USA, 1986; Vol. 45, pp $361 \mathrm{ff}$.

49. Kim, Y.; Ko, Y. H.; Jung, M.; Selvapalam, N.; Kim, K. Photochem. Photobiol. Sci. 2011, 10, 1415. doi:10.1039/c1pp05055a

50. Prokof'ev, E. P.; Karpeiskaya, E. I. Tetrahedron Lett. 1979, 20 , 737-740. doi:10.1016/s0040-4039(01)93560-9

51. Bondi, A. J. Phys. Chem. 1964, 68, 441-451. doi:10.1021/j100785a001

52. Blanco-Lomas, M.; Campos, P. J.; Sampedro, D. Org. Lett. 2012, 14, 4334-4337. doi:10.1021/ol301741g

53. Haasbroek, P. P.; Oliver, D. W.; Carpy, A. J. M. J. Chem. Crystallogr. 1998, 28, 811-814. doi:10.1023/a:1021875603536

54. Asiri, A. M.; Akkurt, M.; Khan, I. U.; Arshad, M. N. Acta Crystallogr., Sect. E: Struct. Rep. Online 2009, 65, 0842. doi:10.1107/s1600536809010216

55. Asiri, A. M.; Ng, S. W. Acta Crystallogr., Sect. E: Struct. Rep. Online 2009, 65, 01746. doi:10.1107/s1600536809024593

56. Roiban, G.-D.; Serrano, E.; Soler, T.; Aullon, G.; Grosu, I.; Cativiela, C.; Martinez, M.; Urriolabeitia, E. P. Inorg. Chem. 2011, 50, 8132-8143. doi:10.1021/ic200564d

57. Haasbroek, P. P.; Oliver, D. W.; Carpy, A. J. M. J. Mol. Struct. 2004, 690, 89-94. doi:10.1016/j.molstruc.2003.11.022

58. Hanson, A. W. Acta Crystallogr., Sect. B: Struct. Crystallogr. Cryst. Chem. 1977, 33, 594-596. doi:10.1107/s056774087700421x

59. Chatterjee, T.; Mandal, M.; Gude, V.; Bag, P. P.; Mandal, P. K. Phys. Chem. Chem. Phys. 2015, 17, 20515-20521. doi:10.1039/c5cp03086b

60. Singh, A.; Rajbongshi, B. K.; Ramanathan, G. J. Chem. Sci. 2015, 127, 941-948. doi:10.1007/s12039-015-0855-5

61. Stoermer, R.; Bachér, F. Ber. Dtsch. Chem. Ges. B 1922, 55 , 1860-1882. doi:10.1002/cber.19220550638

62. Stoermer, R.; Bachér, F. Ber. Dtsch. Chem. Ges. B 1924, 57, 15-23. doi:10.1002/cber.19240570105

63. Kollár, L., Ed. Modern Carbonylation Methods; Wiley-VCH: Weinheim, Germany, 2008. doi:10.1002/9783527621545

64. Mori, M. In Handbook of Organopalladium Chemistry for Organic Synthesis; Negishi, E., Ed.; Wiley-Interscience: New York, NY, USA; Vol. 2, pp $2663 \mathrm{ff}$.

65. Beller, M. In Applied Homogeneous Catalysis with Organometallic Compounds, 2nd ed.; Cornils, B.; Herrmann, W. A., Eds.; Wiley-VCH: Weinheim, Germany; Vol. 1, pp 145-156.

66. Urriolabeitia, E. P.; Laga, E.; Cativiela, C. Beilstein J. Org. Chem. 2012, 8, 1569-1575. doi:10.3762/bjoc.8.179

67. SAINT, Version 5.0 ed; Bruker Analytical X-Ray Systems: Madison, WI, USA, 1998.

68. SADABS, Program for absorption and other corrections; Göttingen University: Göttingen, Germany, 1996.

69. Sheldrick, G. M. Acta Crystallogr., Sect. A: Found. Crystallogr. 1990, 46, 467-473. doi:10.1107/s0108767390000277

70. Sheldrick, G. M. Acta Crystallogr., Sect. A: Found. Crystallogr. 2008, 64, 112-122. doi:10.1107/s0108767307043930 
71. Sheldrick, G. M. Acta Crystallogr., Sect. C: Struct. Chem. 2015, 71 , 3-8. doi:10.1107/s2053229614024218

\section{License and Terms}

This is an Open Access article under the terms of the Creative Commons Attribution License

(http://creativecommons.org/licenses/by/4.0). Please note that the reuse, redistribution and reproduction in particular requires that the authors and source are credited.

The license is subject to the Beilstein Journal of Organic Chemistry terms and conditions:

(https://www.beilstein-journals.org/bjoc)

The definitive version of this article is the electronic one which can be found at:

doi:10.3762/bjoc. 16.98 